\title{
Organizacja pracy kancelaryjnej Zarządu Miejskiego w Puławach w latach 1944-1950*
}

ABSTRAKт: Artykuł prezentuje zagadnienia związane z organizacją kancelarii Zarządu Miejskiego w Puławach w latach 1945-1950. Bazę źródłową stanowiły materiały archiwalne z zespołu Akta miasta Puław, znajdujące się w zasobie Archiwum Państwowego w Lublinie. Ich analiza pozwoliła na dokładne odtworzenie funkcjonowania kancelarii w okresie stosowania systemu dziennikowego, a od 1949 r. systemu bezdziennikowego. Unowocześnienie kancelarii było możliwe dzięki wprowadzeniu normatywów kancelaryjnych - instrukcji kancelaryjnej oraz rzeczowego wykazu akt, odbiegającego od powszechnie stosowanych wówczas wykazów strukturalno-rzeczowych.

sŁowa KLuczowe: Puławy, kancelaria miejska, system dziennikowy, system bezdziennikowy, normatywy kancelaryjne.

Zagadnienia kancelarii miejskiej okresu pierwszego pięciolecia Polski powojennej nie wzbudzały dotychczas większego zainteresowania badaczy. W początkach lat 8o. XX w. ukazała się monografia Zdzisława Chmielewskiego Kancelaria miejska na Ziemiach Zachodnich i Północnych w latach 1945-1950¹, a wcześniej (1966 r.) artykuł Czesława Margasa o organizacji kancelarii Zarządu Miejskiego w Jeleniej

* Artykuł powstał na podstawie pracy magisterskiej pt. Organizacja pracy kancelaryjnej Zarzadu Miejskiego Puław w latach 1944-1950, napisanej w Zakładzie Archiwistyki Instytutu Historii Uniwersytetu Marii Curie-Skłodowskiej w Lublinie pod kierunkiem prof. dr. hab. Janusza Łosowskiego.

${ }^{1}$ Z. Chmielewski, Kancelaria miejska na Ziemiach Zachodnich i Północnych w latach 1945-1950, Szczecin 1982. 
Górze $^{2}$ Z Z nowszych publikacji, część monografii Procesy archiwotwórcze akt miejskich na Mazowszu na przykładzie Piaseczna w latach 1815-1950 (1999 r.) Włodzimierz Bagieński poświęcił kancelarii miejskiej. W podręczniku akademickim Stanisława Nawrockiego Rozwój form kancelaryjnych na ziemiach polskich od średniowiecza do końca XX wieku brak jest omówienia kancelarii miejskiej okresu powojennego ${ }^{4}$. Nasuwa się więc wniosek, że stan badań nad kancelarią miejską jest niewystarczający, a tak wyraźna luka skłania do podjęcia takich badań, zwłaszcza odnoszących się do kancelarii miast Lubelszczyzny.

\section{Struktura władz miejskich}

W latach 1944-1950 organizację władzy administracji terenowej na szczeblu miejskim stanowiły miejskie rady narodowe pełniące funkcje wykonawcze wobec zarządów miejskich, ich organów wykonawczych. Prawną podstawą zakresu działania miejskich rad narodowych była ustawa Krajowej Rady Narodowej z dnia 11 IX 1944 r. o organizacji i zakresie działania rad narodowych ${ }^{5}$, powołująca rady jako tymczasowe organy uchwałodawcze i samorządowe. Nowela ustawy z 3 I 1946 r. pozbawiła rady charakteru tymczasowości, od tego momentu rady narodowe stały się organami działalności publicznej oraz powołującymi i kontrolującymi rządowe i samorządowe organy wykonawcze. System rad narodowych, recypowany z rozwiązań radzieckich, został oparty na zasadzie jednolitości władzy, podkreślanej przez hierarchiczną strukturę rad. Rady wszystkich szczebli: wojewódzkich, powiatowych, miejskich i gminnych, podlegały Krajowej Radzie Narodowej. Aktem prawnym, który restytuował instytucję samorządu terytorialnego, był dekret z dnia 23 XI 1944 r. o organizacji i zakresie działania samorządu terytorialnego ${ }^{6}$. Przepisy, których nie obejmował dekret, uzupełniono kilkoma

${ }^{2}$ C. Margas, Zarzad Miejski i Miejska Rada Narodowa w Jeleniej Górze w latach 1945-1950, ich kancelaria i zasób aktowy, „Archeion” T. 6, 1966, s. 221-240.

${ }^{3}$ W. Bagieński, Procesy archiwotwórcze akt miejskich na Mazowszu na przykładzie Piaseczna w latach 1815-1950, Warszawa 1999.

${ }^{4}$ S. Nawrocki, Rozwój form kancelaryjnych na ziemiach polskich od średniowiecza do końca XX wieku, Poznań 1998.

${ }^{5}$ Ustawa zawarta została w Dzienniku Ustaw Rzeczypospolitej Polski (dalej Dz.U. RP), 1944, $\mathrm{nr}$ 5, poz. 22. Wcześniej, podczas okupacji, w okresie konspiracyjnym, działalność rad narodowych określał uchwalony 1 I 1944 r. przez Krajową Radę Narodową „Statut Tymczasowy Rad Narodowych”. Statut został opublikowany w periodyku „Rada Narodowa”, 1944.

${ }^{6}$ Dz.U. RP, 1944, nr 14, poz. 74 
artykułami ustawy przedwojennej z 23 III 1933 r. o częściowej zmianie samorządu terytorialnego. W latach 1944-1950 konsekwencją powyższych rozwiązań był dualizm władzy i administracji, przejawiający się w istnieniu obok siebie pionu administracji rządowej i samorządowej oraz rad narodowych. Dualizm w strukturze aparatu administracji miasta $\mathrm{z}$ jednej strony uwidocznił się w działalności prezydenta lub burmistrza, kierujących pracą zarządów miejskich, z drugiej natomiast występowały miejskie rady narodowe jako naczelne organy uchwałodawcze oraz organy działalności publicznej posiadające osobowość prawną.

Dualistyczny charakter administracji terenowej przetrwał do wejścia w życie ustawy z 20 III 1950 r. o terenowych organach jednolitej władzy państwowej ${ }^{7}$, co w konsekwencji, po stopniowym ograniczaniu od 1945 r. roli samorządu terytorialnego, doprowadziło do całkowitej jego likwidacji. Wówczas nastąpiło radykalne zreorganizowanie aparatu państwowego w terenie. Funkcje organów wykonawczych przejęły rady narodowe i ich prezydia.

Struktura władz miejskich Puław w latach 1945-1950 nie odbiegała zasadniczo od obowiązującego wówczas modelu ogólnopolskiego miast niewydzielonych. Puławy, ze względu na zasady podziału i liczbę mieszkańców ${ }^{8}$, mieściły się w kategorii miast niewydzielonych. Początek funkcjonowania Miejskiej Rady Narodowej związany jest jeszcze z okresem konspiracyjnym. Już 1 IX 1944 r. Powiatowa Rada Narodowa, powołując się na „Statut Tymczasowy Rad Narodowych”, ustanowiła ją organem tymczasowym ${ }^{9}$. Wówczas działalność Rady koncentrowała się wokół wprowadzania zarządzeń zgodnych z linią polityczną Polskiego Komitetu Wyzwolenia Narodowego ${ }^{10}$. Brak natomiast bardziej szczegółowych informacji o zadaniach Rady w tym okresie. Fragmentaryczne dane, zachowane w materiale źródłowym, wspominają jedynie, że przeważnie pełniła ona funkcje zalecone przez

7 Tamże, 1950, nr 14, poz. 130.

${ }^{8}$ Po II wojnie światowej miasta zostały podzielone na wydzielone, posiadające ponad 25000 mieszkańców, i niewydzielone, które liczyły ich do 25000. W 1945 r. liczba mieszkańców Puław wynosiła 9200, w 1950 r. wzrosła do 11806. Zob. Archiwum Państwowe w Lublinie (dalej APL), Akta miasta Puław (dalej AmP), sygn. 3, s. 24, Załącznik do protokołu Prezydium Miejskiej Rady Narodowej w Puławach z 9 III $1951 \mathrm{r}$.

9 Organizacja struktur rad narodowych w powiecie przebiegała stosunkowo sprawnie, w ścisłej współpracy z lubelską Wojewódzką Radą Narodową, która została utworzona już 18 II 1944 r. Zob. W. Skrzydło, Administracja państwowa i sądownictwo, [w:] Dzieje Lubelszczyzny. T. 2, Warszawa 1979, s. 97.

10 APL, AmP, sygn. 6, s. 1. 
władze wojskowe ${ }^{11}$. Inauguracyjne posiedzenie Rady po wyzwoleniu odbyło się 23 I 1945 r., wówczas nastąpiło oficjalne jej ukonstytuowanie. Przez kilka miesięcy, do $18 \mathrm{~V} 1945 \mathrm{r}$. Rada pełniła również funkcję władzy wykonawczej, aż do czasu wyboru Zarządu Miejskiego ${ }^{12}$. Uchwalenie wrześniowej ustawy zobligowało Prezydium Powiatowej Rady Narodowej do rozwiązania dotychczasowej Rady i przeprowadzenia 29 V 1945 r. nowych wyborów ${ }^{13}$. Skład osobowy Rady, która liczyła 24 członków, kilkakrotnie ulegał zmianom. Praktycznie od początku działalności Rady na kryterium doboru członków decydujący wpływ miał element polityczny. Rok 1947 i zwycięstwo partii Bloku Stronnictw Demokratycznych: PPR, PPS, SL i SD podczas wyborów do Sejmu Ustawodawczego wyznaczyły tendencje jeszcze bardziej widocznego upolitycznienia składu Rady. Przykładowo, w 1945 r. jedynie $20 \%$ radnych było zdeklarowanych politycznie ${ }^{14}$. Dwa lata później do PPR należało siedmiu członków Rady, do PPS dziewięciu, dwóch reprezentowało SL. Puławska Miejska Rada Narodowa działała na posiedzeniach plenarnych, z reguły odbywających się raz w miesiącu, w drodze podejmowania uchwał. Zasadnicze funkcje Rady sprowadzały się do takich kwestii, jak ustalanie budżetu, powoływanie oraz kontrolowanie organów wykonawczych, Zarządu Miejskiego oraz innych podlegających jej instytucji ${ }^{15}$. Ponadto działalność Rady przejawiała się poprzez jej organy, Prezydium oraz komisje. Prezydium stanowiło integralną część Rady, kierowało jej pracami i reprezentowało na zewnątrz. Skład Prezydium tworzyli: przewodniczący, jego zastępca oraz trzech członków ${ }^{16}$. Natomiast komisje były organami pomocniczymi, doradczymi i opiniodawczymi w zakresie swoich kompetencji, ale w ówczesnym okresie pełniły też rolę czynnika aktywizującego do współpracy i poparcia Miejskiej Rady Narodowej w jak najliczniejszych kręgach społecznych. Ustawa wrześniowa regulowała liczbę stałych komisji, takich jak: finansowo-budżetowa, oświatowa i kontroli. W przypadku komisji, przy puławskiej Radzie dopiero w połowie $1945 \mathrm{r}$. podjęły one właściwą działalność (wcześniej działały sekcje mające charakter przejściowy $)^{17}$. Komisje kilkakrotnie ulegały reorganizacjom ${ }^{18}$.

11 Tamże, sygn. 7, s. 22, Sprawozdanie przewodniczącego Miejskiej Rady Narodowej (załącznik $\mathrm{nr} 2$ do protokołu $\mathrm{nr} 4 \mathrm{z} 11$ VI $1950 \mathrm{r}$.).

12 Tamże.

13 Tamże, sygn. 21, s. 228, Protokół z posiedzenia MRN z 29 V 1945 r.

14 Tamże, sygn. 20, s. 11-12, Sprawozdanie z działalności MRN do PRN za czerwiec 1945 r.

15 Tamże, sygn. 7, s. 22.

16 Tamże, sygn. 1, s. 5, Protokół nr 1 z posiedzenia PMRN.

17 Tamże, sygn. 6, s. 1, 11, 15.

18 Zob. szerzej: tamże, sygn. 22, s. 4, 9, 21-23; sygn. 13, s. 1-2, 13-14, 83; sygn. 7, s. 15. 
Zarząd Miejski został formalnie powołany 25 VI 1945 r. ${ }^{19}$ W skład Zarządu wchodzili: burmistrz, jego zastępca oraz trzech ławników. Burmistrz w ramach swoich obowiązków organizował pracę Zarządu, jego Biura (jako zwierzchnik wszystkich pracowników Biura), współpracował z Miejską Radą Narodową, partiami politycznymi, organizacjami społecznymi oraz z Wydziałem Samorządowym Urzędu Wojewódzkiego w Lublinie. Ponadto w jego ręku skupiły się zagadnienia związane z ustalaniem budżetu oraz organizacją służby zdrowia i nadzorem nad nią ${ }^{20}$. Działalność kolegialna Zarządu znajdowała odbicie we wspólnie podejmowanych decyzjach, które zapadały podczas posiedzeń. Szczegółowe kwestie poruszane na odbywających się z reguły co miesiąc spotkaniach przedstawiają zachowane protokoły $^{21}$. Generalnie dotyczyły one działalności władz w odniesieniu do całokształtu gospodarki miejskiej, takie jak ustalanie stawek czynszu dzierżawnego, rozpatrywanie podań z zakresu opieki społecznej, kosztów leczenia, udzielania zapomóg, ustalania projektów budżetu i planu pracy. Zarząd był również decydentem w sprawie przydziału mieszkań komunalnych ${ }^{22}$.

Strukturę organizacyjną Biura Zarządu określał statut z 10 XI 1949 r. $^{23}$ Jego wprowadzenie zakończyło kilkuletni okres funkcjonowania Biura Zarządu bez formalnych przepisów określających organizację poszczególnych referatów. Dotychczas panowała pewna dowolność, a wydziały tworzono w zależności od aktualnych potrzeb. Fakt ten nie miał pozytywnego wpływu na sprawną działalność Biura, zatem statut miał niewątpliwie istotne znaczenie dla jego stabilizacji i był momentem przełomowym w procesie przeobrażeń organizacyjnych Zarządu. Statut był wzorowany na „Wzorcowym Statucie Organizacyjnym dla Biur Zarządów Miejskich Ministerstwa Administracji Publicznej z 20 lipca 1948 r.", który docelowo miał usprawnić administrację terenową. Ministerstwo Administracji Publicznej opracowało statuty dla czterech kategorii miast, przyjmując kryterium liczby mieszkańców. W ramach zaleconego statutu podział Biura Zarządu przedstawiał się następująco:

1. Referat Organizacyjny kierowany przez sekretarza

2. Referat Finansowo-Budżetowy kierowany przez rachmistrza

\footnotetext{
19 Tamże, sygn. 6, s. 20, Protokół MRN z 25 VI 1945 r.

20 Tamże, sygn. 28, s. 23-25.

21 Tamże, sygn. 33, s. 1-71, Książka protokołów posiedzeń ZM z 1948-1949 r. oraz sygn. 187, Protokoły wspólnych posiedzeń PMRN i ZM.

22 Tamże, sygn. 102, Zeszyt korespondencji Referatu Kwaterunkowego przy ZM z 1946 r. oraz sygn. 103, Skorowidz Referatu Kwaterunkowego.

23 Tamże, sygn. 34, s. 1-4, Statut organizacyjny ZM w Puławach wprowadzony 10 XII 1949 r. przez MRN.
} 
3. Referat Administracyjny kierowany przez referenta administracyjnego

4. Referat Spraw Technicznych i Majątkowych kierowany przez burmistrza przy pomocy urzędnika technicznego.

Odrębnymi komórkami organizacyjnymi Biura były Kasa Miejska (prowadzona przez kasjera) oraz Urząd Stanu Cywilnego. Biuro Ewidencji i Kontroli Ruchu Ludności wchodziło w skład Referatu Administracyjnego, zaś Kancelaria Zarządu stanowiła część Referatu Organizacyjnego. Ogłoszenie statutu nie zakończyło ewolucji wewnętrznej organizacji Biura Zarządu. W marcu $1950 \mathrm{r}$. nieco go zmodyfikowano, uzupełniając o Referat Wojskowy pod kierownictwem specjalnego referenta ${ }^{24}$.

Miejska Rada Narodowa i Zarząd Miejski funkcjonowały do 11 VI 1950 r. $^{25}$ Dnia 3 VI tego roku odbyła się uroczysta sesja Powiatowej Rady Narodowej, podczas której dokonano ujednolicenia organów władzy terenowej w powiecie ${ }^{26}$. Wraz z likwidacją Miejskiej Rady Narodowej nastąpił kres działalności również jej organu wykonawczego.

\section{Kancelaria prowadzona systemem dziennikowym}

Działalność kancelarii można podzielić na dwa okresy:

- okres, kiedy kancelaria prowadzona była systemem dziennikowym,

- okres, kiedy kancelaria przeszła na system bezdziennikowy.

Za cezurę rozgraniczającą można uznać rok 1949, kiedy wprowadzono instrukcję kancelaryjną i wykaz akt. Trudno jednak uchwycić wyraźną granicę, a tym samym stwierdzić, kiedy rzeczywiście nastąpiło unowocześnienie kancelarii. Raczej mało prawdopodobne, że kancelaria od razu przeszła na system bezdziennikowy.

Wydaje się natomiast niemal pewne, że w pierwszych latach funkcjonowania Zarządu Miejskiego kancelaria prowadzona była systemem dziennikowym. Prawdopodobnie stan ten trwał co najmniej do momentu wprowadzenia w 1949 r. instrukcji kancelaryjnej i wykazu akt. W materiale źródłowym nie udało się odnaleźć innych

${ }^{24}$ Tamże, sygn. 7, s. 6, Protokół MRN nr 2/50 z marca 1950 r.

25 Tamże, s. 13, Protokół nr 1 z sesji MRN z 11 VI 1950 r.

${ }^{26}$ Zob. J. Trześniak, U progu Polski Ludowej, [w:] Puławy dawne i nowe, red. J. Trześniak, Lublin 1987, s. 361. 
wcześniejszych normatywów kancelaryjnych, które świadczyłyby o wcześniejszym unowocześnieniu kancelarii. Należy przypuszczać, że kancelaria raczej nie miała tych normatywów. W tym miejscu warto zwrócić uwagę na niezwykle trudną sytuację po 1944 r., czego odzwierciedleniem była również, przynajmniej na początku, prowizoryczna organizacja kancelarii. W okresie okupacji powszechne było zjawisko rozproszenia wykwalifikowanego personelu biurowego, który zastępowano urzędnikami niemającymi dostatecznego wykształcenia, nierzadko z klucza partyjnego. Niestabilna struktura Zarządu oraz jej wielokrotne zmiany dodatkowo utrudniały sprawne funkcjonowanie kancelarii. Dopiero dzięki statutowi organizacyjnemu Zarządu kancelaria znalazła się w ramach jego struktury, a ostateczny podział na komórki organizacyjne umożliwił unormowanie pracy kancelarii oraz stał się podstawą do wprowadzenia normatywów kancelaryjnych (statut zapowiadał ich wprowadzenie w przyszłości).

Na pewno prowadzenie kancelarii systemem dziennikowym na tym etapie przeobrażeń kancelaryjnych było zdecydowanie łatwiejsze. Przepisy zezwalały na tymczasowe stosowanie rejestracji dziennikowej, ale władze równocześnie podjęły działania mające na celu wyegzekwowanie przechodzenia na system bezdziennikowy ${ }^{27}$. Tak było w przypadku puławskiej Miejskiej Rady oraz jej organów pomocniczych, prezydium i komisji, których obowiązki związane z prowadzeniem czynności kancelaryjnych wykonywała kancelaria Zarządu. Jednak próby zorganizowania w 1947 r. samodzielnego biura Prezydium nie powiodły się. Nie są znane przypadki, aby w praktyce stosowano wytyczne uchwały, na podstawie której funkcjonowanie kancelarii Prezydium miało się opierać na systemie bezdziennikowym przy pomocy wprowadzonego dla każdego referatu wykazu akt ${ }^{28}$. Pojawiły się również naciski, aby dla Miejskiej Rady urządzić oddzielne biuro, $\mathrm{z}$ przeznaczonym dla niego personelem ${ }^{29}$. Jednak aż do $1950 \mathrm{r}$. to kancelaria Zarządu prowadziła czynności kancelaryjne również swojego organu uchwałodawczego. Taka prawidłowość oznaczała, że zmiany w systemie kancelaryjnym Biura ZM dotyczyły wszystkich organów miejskich.

Dziennik podawczy kancelarii Zarządu niestety się nie zachował. Nie można więc jednoznacznie stwierdzić, w jaki sposób był prowadzony. Fakt, że rejestracja

\footnotetext{
27 Przykładowo: „Instrukcja kancelaryjna z 25 X 1945 r.” ogłoszona w „Biuletynie Urzędu Generalnego Pełnomocnika Rządu RP dla Ziem Odzyskanych”. Por. Z. Chmielewski, dz. cyt., s. 142 .

28 AmP, sygn. 28, s. 10-12, Uchwała PMRN nr XII/28 z 1947 r.

${ }^{29}$ Tak wynika z przeprowadzonej lustracji MRN. Zob. tamże, sygn. 6, s. 57 i 57v, Protokół $\mathrm{z}$ listopada $1947 \mathrm{r}$.
} 
taka miała miejsce, potwierdza analiza znaków ewidencyjnych pism. W systemie dziennikowym istotny był numer kolejny dziennika, pod którym pismo było rejestrowane, ponieważ numer ten łamany przez dwie cyfry roku kalendarzowego stanowił znak pisma. Na pismach Zarządu Miejskiego z reguły figurują znaki złożone z tych dwóch elementów: L. Dz. $1 / 47^{30}$; L. Dz. 1200/47 $17^{31}$, L. 336/48 ${ }^{32}$. Zdarzało się również, że kancelaria znakowała pisma przy użyciu cyfr rzymskich, określając nimi referat: L. I-8/47 ${ }^{33}$; L. III. 10/46 $6^{34}$, lub bez wyszczególnienia roku kalendarzowego: L. IX-3 ${ }^{35}$. Często spotyka się dodatkowe oznaczenia w postaci skrótu ZM, które stosowano, aby odróżnić pisma Miejskiej Rady i Prezydium, np. L. I-4/ZM, L. I-4/RN, L. I-2/RN ${ }^{36}$. Ta pewnego rodzaju dowolność w znakowaniu pism świadczy o chaotycznym prowadzeniu kancelarii, braku konsekwencji i niskich kwalifikacjach personelu. Nie można natomiast jednoznacznie stwierdzić, czy pisma podlegały rejestracji w osobnym dzienniku wydziałowym. Raczej nie, gdyż w znakach pism brak jest dodatkowych oznaczeń, które świadczyłyby o prowadzeniu tej dodatkowej pomocy ewidencyjnej.

W okresie stosowania systemu dziennikowego kancelaria była scentralizowana, co w konsekwencji powodowało skomplikowany i długotrwały obieg pism, opóźniający załatwianie spraw. Struktura personelu stricte kancelaryjnego, który miał bezpośredni wpływ na poszczególne etapy obiegu pisma, była znacznie rozbudowana. W 1945 r. biuro składało się z następujących pracowników: maszynistki i czterech pomocy biurowych, w 1947 r. aż z sześciu kancelistów oraz maszynistki, natomiast rok później były dwie maszynistki, trzech kancelistów oraz pomoc buchalterska. Dodatkowo Zarząd zatrudniał pracowników zajmujących się doręczaniem korespondencji. Należeli do nich gońcy oraz woźny. Dane te zostały oparte na wykazach pracowników Biura Zarządu, brak w nich jednak informacji o obowiązkach wymienionych urzędników (pojawia się jedynie wzmianka, że maszynistka sporządzała sprawozdania poszczególnych referatów) ${ }^{37}$, nie można

${ }^{30}$ Tamże, sygn. 28, Pismo ZM do Związku byłych Więźniów Politycznych w Puławach z 20 XI $1947 \mathrm{r}$.

${ }^{31}$ Tamże, sygn. 74, s. 84, Pismo ZM do Starostwa Powiatowego z 9 XII 1947 r.

32 Tamże, sygn. 90, s. 243, Pismo ZM do Starosty Powiatowego z 23 IV 1948 r.

33 Tamże, sygn. 28, Pismo Ref. Organizacyjnego z 14 VIII 1947 r.

${ }^{34}$ Tamże, sygn. 106, s. 20, Pismo ZM z 12 IX 1946 r.

35 Tamże, sygn. 115, s. 59, Pismo ZM z 21 II 1947 r. do Regionalnej Dyrekcji Planowania Przestrzennego.

36 Tamże, sygn. 131, s. 78, Pismo ZM z 27 X 1945 r.; sygn. 84, s. 7, Pismo PMRN z 14 IX 1945 r. oraz sygn. 20, s. 5, Pismo MRN z 14 IX 1945 r. do przewodniczącego Komisji Rewizyjnej.

37 Tamże, sygn. 31, s. 55, 99-101, 180-182. 
zatem precyzyjnie omówić ich rzeczywistej roli w kształtowaniu poszczególnych etapów obiegu pism. Należy też zwrócić uwagę, że wśród personelu nie było registratora, który odgrywał ówcześnie ważną rolę, gdyż czuwał nad całym procesem obiegu pism.

Dokumentacja, jaka narastała $\mathrm{w}$ toku załatwiania spraw, była przechowywana w szafach sekretariatu ${ }^{38}$. Nie było wówczas specjalnie wydzielonego pomieszczenia, przeznaczonego na składnicę akt. Akta, jak określano, znajdowały się w odpowiednich teczkach. Najprawdopodobniej była to dokumentacja z działalności wszystkich referatów, nie tylko Zarządu, ale także Miejskiej Rady Narodowej oraz Prezydium. Na podstawie polustracyjnego sprawozdania rachunkowości, kasowości oraz gospodarki Zarządu Miejskiego, dokonanego przez Powiatowego Inspektora Samorządu Gminnego, można ustalić, jakiego rodzaju dokumentację wytwarzał Referat Budżetowo-Gospodarczy. Były to: księgi ewidencyjne, książki rachunkowe, kartoteki ewidencji ludności, dzienniki kasowe, dzienniki - główna, książki kontowe, okólniki. Dokumentacja nie była prowadzona według układu rzeczowego, najprawdopodobniej posługiwano się układem chronologicznym, według numerów dziennika podawczego. Część informacji o narastającej dokumentacji i stanie jej prowadzenia można odnaleźć w zachowanych protokołach zdawczo-odbiorczych, które każdy ustępujący referent musiał sporządzić i przekazać swojemu następcy. Wynika z nich, że akta zakończone nie były uporządkowane. Te spostrzeżenia świadczą o niedociągnięciach w kwestii stanu organizacji kancelarii. Pozostawiał on wiele do życzenia, a niejednokrotne upomnienia pokontrolne władz nadrzędnych raczej nie przynosiły zamierzonego rezultatu.

\section{Kancelaria prowadzona systemem bezdziennikowym}

Momentem przełomowym dla kancelarii puławskiego Zarządu Miejskiego było przejście na system bezdziennikowy. Trudno stwierdzić, kiedy to nastąpiło, o czym powyżej wspomniano. W praktyce wprowadzenie tego systemu miało stanowić unowocześnienie kancelarii. System bezdziennikowy znalazł zastosowanie w urzędach administracji państwowej jeszcze przed wojną na mocy

\footnotetext{
${ }^{38}$ Sekretariat należy rozumieć jako registraturę, czyli miejsce przeznaczone do przechowywania dokumentów potrzebnych do pracy bieżącej. Por. Polski słownik archiwalny, red. W. Maciejewska, Warszawa 1974, s. 70.
} 
ustawy z 24 VIII $1931 \mathrm{r}^{39}$ Organy samorządu terytorialnego zaczęły go jednak stosować dopiero w latach $1934-1935^{40}$. Reforma ta oznaczała usprawnienie pracy kancelaryjnej polegające na wprowadzeniu decentralizacji czynności kancelaryjnych, która w konsekwencji miała doprowadzić do odciążenia kancelarii głównej na rzecz merytorycznych komórek urzędu oraz pracujących tam referentów. To oni w ramach swoich obowiązków zajmowali się łączeniem akt w sprawy, ich rejestrowaniem, oznaczaniem i przechowywaniem. Po 1945 r. oczywiste było dążenie władz do powrotu do rozwiązań w zakresie biurowości z okresu przedwojennego. Podstawę funkcjonowania kancelarii stanowiły akta normatywne, tj. instrukcja kancelaryjna i wykaz akt. W przypadku kancelarii zarządów miast niewydzielonych obowiązywała instrukcja oparta na systemie bezdziennikowym dla zarządów gmin wiejskich, opracowana i ogłoszona w 1933 r. Ta instrukcja wiązała się z przywołaną wyżej reformą biurowości, miała zasięg ogólnokrajowy i obejmowała również m.in. tereny Ziem Odzyskanych ${ }^{41}$. Jej wytyczne stanowiły też prawną podstawę do wprowadzenia przez Zarząd Miejski instrukcji kancelaryjnej, której konstrukcja była analogiczna do wzorcowej, zaleconej przez Ministerstwo Spraw Wewnętrznych okólnikiem nr 12 z 16 XI 1933 r. Instrukcja kancelaryjna została ogłoszona zarządzeniem burmistrza i zatwierdzona przez przewodniczącego Miejskiej Rady Narodowej 1 III 1949 r. ${ }^{42}$, z pewnym opóźnieniem $\mathrm{w}$ porównaniu do innych miast niewydzielonych ${ }^{43}$. Zgodnie $\mathrm{z}$ funkcjami, jakie miała pełnić, szczegółowo określała zasady postępowania z aktami w trakcie ich narastania, od momentu wpłynięcia ich do kancelarii aż do przekazania do $\operatorname{archiwum}^{44}$. Instrukcja kancelaryjna zawierała następujące postanowienia: zakres przepisów, czynności kancelaryjne, odbiór i rozdział pism, przeglądanie korespondencji przez burmistrza, obieg akt, rejestracja akt, rejestracja spraw periodycznych, sprawy niepodlegające rejestracji, numer sprawy, forma załatwienia, sporządzanie czystopisów, podpisywanie i data, wysyłanie i doręczanie pism, przypomnienia, teczki podręczne, przechowywanie akt terminowych, przechowywanie akt ostatecznie załatwionych, przechowywanie okólników, sprawozdania

\footnotetext{
39 „Monitor Polski”, 1939, nr 196, poz. 273.

${ }^{40}$ H. Robótka, Kancelaria urzędów administracji państwowej w II Rzeczypospolitej. (Procesy aktotwórcze), Toruń 1993.

${ }^{41}$ Zob. Z. Chmielewski, dz. cyt., s. 136-139.

${ }^{42}$ Por. AmP, sygn. 34, s. 4-15.

${ }^{43}$ Przeważająca liczba zarządów miast mniejszych ogłaszała instrukcje kancelaryjne już w latach 1946-1947. Por. Z. Chmielewski, dz. cyt., s. 143.

${ }^{44}$ Por. definicję instrukcji kancelaryjnej w Polskim słowniku archiwalnym, s. 37.
} 
periodyczne, księgi nieposiadające charakteru rejestrów kancelaryjnych, księgi uchwał, kontrola, przepisy końcowe i wykonawcze.

Do instrukcji został załączony wykaz akt, który stanowił jej integralną część. W latach 1945-1950 ogólnie przyjęty był wykaz akt strukturalno-rzeczowy. Powszechność stosowania tego rodzaju wykazów, nie tylko na najniższym szczeblu samorządowym, wynikała z tego, że ich praktyczne stosowanie było łatwiejsze, tym bardziej że ówczesne urzędy nie reprezentowały najwyższego poziomu pod względem organizacyjnym ${ }^{45}$. Dla urzędów gminnych został opracowany specjalny wykaz akt, w którym hasła otrzymały jednolitą numerację ciągłą, $\mathrm{z}$ podziałem na komórki organizacyjne urzędu ${ }^{46}$. Wykaz akt puławskiego Zarządu składał się z 38 tytułów teczek. Każdej pozycji odpowiadała teczka o tym samym numerze. Zasadniczą różnicą tego wykazu, odróżniającą go od typowych strukturalno-rzeczowych, był brak podziału według struktury organizacyjnej Zarządu Miejskiego. Taki wykaz akt można zatem nazwać jedynie rzeczowym. W celu ułatwienia dotarcia do właściwych teczek i usprawnienia pracy referentów burmistrz wydał odrębne zarządzenie, na podstawie którego każdy numer teczki przyporządkowano do właściwego referatu ${ }^{47}$. Niewątpliwie tego typu wykaz akt powodował pewne ograniczenia w jego rozbudowie. W związku z koniecznością dodania nowego hasła, przewidziano specjalne oznaczenia literowe. Przykładowo, zakładając nową podteczkę w ramach nowego numeru z wykazu akt, oznaczano ją w następujący sposób: 7a, 7b, 7c itd. Trzeba dodać, że oprócz tego mankamentu wykaz nie posiadał kwalifikacji na kategorie archiwalne, co było dużym utrudnieniem podczas czynności brakowania akt ${ }^{48}$.

Powyższe normatywy kancelaryjne były podstawą funkcjonowania kancelarii Zarządu Miejskiego i Miejskiej Rady Narodowej, która nie posiadała własnego aparatu wykonującego czynności biurowe. To kancelaria Zarządu, podobnie zresztą jak w okresie stosowania systemu dziennikowego, prowadziła dokumentację dotyczącą działalności Miejskiej Rady i jej organów, Prezydium i komisji. Regulamin Miejskiej Rady Narodowej wyraźnie wspomina o obowiązku wykonywania

45 Takie wykazy akt znalazły zastosowanie również w urzędach administracji państwowej. Zob. A. Muszyński, Rola wykazu akt w kształtowaniu zasobu aktowego, „Archeion” T. 60, 1974, s. 25-26.

${ }^{46}$ Zob. S. Podwiński, P. Typiak, Instrukcja kancelaryjna dla urzędów gminnych z objaśnieniami i szczegółowymi wskazówkami, Warszawa 1934, s. 41-47.

47 AmP, sygn. 34, s. 29, Zarządzenie burmistrza nr 4/49.

$48 \mathrm{Na}$ ten problem zwrócił uwagę również S. Nawrocki w artykule Porządkowanie akt ze szczebla wojewódzkiego, „Archeion” T. 51, 1969, s. 57. 
prac biurowych wszystkich organów miejskich przez kancelarię Zarządu ${ }^{49}$. Jeszcze po reformie marcowej, co najmniej do końca 1950 r., kancelaria była prowadzona tym systemem. Tak wynika z protokołu posiedzenia Prezydium Miejskiej Rady Narodowej, na którym dopiero planowano opracowanie nowej instrukcji kancelaryjnej, dostosowanej do struktury nowych organów miejskich ${ }^{50}$.

Po wprowadzeniu w kancelarii Zarządu Miejskiego systemu bezdziennikowego wszystkie czynności kancelaryjne uległy decentralizacji. Referenci, którzy wcześniej odpowiadali jedynie za treściowe załatwienie spraw, przejęli dodatkowe obowiązki kancelaryjne, takie jak rejestracja pism, łączenie ich w sprawy, prowadzenie i przechowywanie teczek. Niewątpliwie redukcja części personelu podyktowana była względami oszczędnościowymi oraz dążeniem do zlikwidowania skomplikowanego obiegu pism, opóźniającego załatwienie sprawy. Dodatkowo tendencję taką wymuszały przepisy instrukcji kancelaryjnej. W konsekwencji ograniczono personel kancelaryjny do dwóch urzędników: maszynistki i kancelisty ${ }^{51}$.

Przesyłki otwierane były przez sekretarza, a w przypadku jego nieobecności przez inną upoważnioną do tego osobę. Sekretarz odpowiadał za sprawdzanie, czy poszczególne sprawy rzeczywiście należą do kompetencji Zarządu i czy mogą być przez niego załatwione. Ponadto zwracał uwagę, czy pisma posiadają podaną liczbę załączników i czy zawartość koperty zgadza się z jej oznaczeniami. Do obowiązków sekretarza należało nadanie pismom pieczątki wpływu, czyli umieszczenie z lewej strony, pod treścią pisma, daty wpływu, nazwy odbiorcy (ZM w Puławach), informacji o liczbie załączników, ewentualnie skrótu „BR” (tzn. bez rejestracji). Sekretarz miał prawo nanoszenia adnotacji dotyczących trybu i sposobu załatwiania spraw. Po przejrzeniu treści pism, przydzielał je poszczególnym referentom do dalszego załatwienia. Czynność ta odbywała się za pokwitowaniem (tak wynika z rozdziału czwartego instrukcji kancelaryjnej). Można tu mówić o pewnej niekonsekwencji, ponieważ przepisy kancelaryjne z $1931 \mathrm{r}$. zalecały przyspieszenie obiegu akt w urzędach i zmniejszenie liczby punktów zatrzymania pism poprzez likwidację wewnętrznych pokwitowan ${ }^{52}$. Pisma tajne i poufne przeglądał burmistrz, nanosił wskazówki i zwracał do załatwienia sekretarzowi.

\footnotetext{
${ }^{49}$ AmP, sygn. 22, s. 1v, Artykuł siódmy regulaminu MRN (załącznik do protokołu nr 10 z posiedzenia 19 XII 1949 r.).

50 Tamże, sygn. 2, s. 15, Protokół z posiedzenia PMRN z 3 X 1950 r.

51 Tamże, sygn. 114, s. 32, Pismo ZM z 17 V 1949 r.

${ }^{52}$ K. Kasperek, Procesy archiwizacji w Urzędzie Wojewódzkim Kieleckim (1919-1939), „Archeion” T. 71, 1981, s. 123-132.
} 
Referenci rejestrowali pisma w spisach spraw lub rejestrach kancelaryjnych. Do rejestracji pism typowych służyły rejestry kancelaryjne, posiadające formę skorowidza alfabetycznego. W takim rejestrze należało odnotować liczbę porządkową pod daną literą oraz imię i nazwisko. Rejestry miały zatem charakter osobowy (imienny) i stanowily osobne tomy, oznaczone symbolami literowymi. Wykaz rejestrów, po konsultacjach z władzą nadrzędną, ustalał Zarząd Miejski. Taką formę rejestracji stosowały dwa referaty: Administracyjny oraz Spraw Technicznych i Majątkowych. Do pierwszego zostały przyporządkowane rejestry oznaczone symbolami: Z, Zap., L, O, D, C, K, A, D.r., Dr, P, do drugiego natomiast symbolem B. W zespole zachowały się dwa takie rejestry. Rejestr noszący tytuł „Rejestr wydanych zaświadczeń i pobranych opłat kancelaryjnych” o symbolu „Z” był prowadzony w ramach działalności Referatu Administracyjnego ${ }^{53}$. Jego ramy chronologiczne obejmują lata 1949-1951. Nieco inną praktykę w prowadzeniu rejestru stosował ten sam referat w „Rejestrze kosztów opieki społecznej”, oznaczonym symbolem „O"54. W tym przypadku pisma rejestrowano chronologicznie. Prowadzony w latach 1949-1950 rejestr ogółem zawiera 114 wpisów na dwudziestu czterech stronach. Nasuwa się zatem wniosek, że kancelaria Zarządu stosowała się do zaleceń instrukcji co najmniej w tych dwóch przypadkach spośród dwunastu pozycji rejestrów.

Pozostałe pisma rejestrowano w spisach spraw, dołączonych do każdej teczki po zakończeniu roku. Niestety w zespole nie natrafiono na oryginalną teczkę, która zawierałaby taki spis. Nie wiadomo, w jakim stopniu referenci stosowali się do zaleceń instrukcji kancelaryjnej w kwestii prowadzenia spisów spraw. Niewykluczone, że nie były one dołączane do każdej teczki, ponieważ system bezdziennikowy przewidywał, iż w przypadku teczek zakwalifikowanych do kategorii A należało dołączać spisy ${ }^{55}$.

Instrukcja kancelaryjna nie uwzględniała podziału na kategorie, co oczywiście było dużą wadą, ale fakt ten mógł również powodować pewne niejasności w kwestii prowadzenia spisów spraw. Każde kolejne pismo dotyczące danej sprawy otrzymywało jako symbol rozpoznawczy znak akt składający się z następujących elementów: skrótu nazwy referatu, kolejnej pozycji wykazu akt oraz numeru ze spisu spraw. Instrukcja kancelaryjna nadmieniała, że w znaku pism mogły

\footnotetext{
53 AmP, sygn. 29.

54 Tamże, sygn. 97.

55 I. Radtke, Organizacja pracy kancelaryjnej, [w:] Archiwistyka praktyczna dla archiwistów zakładowych, red. S. Kłys, Poznań 1986, s. 33.
} 
znaleźć się, oprócz skrótów nazw referatów, również symbole innych samodzielnych jednostek, mianowicie Miejskiej Rady Narodowej - MRN oraz Urzędu Stanu Cywilnego - USC.

Na pismach z tego okresu możemy odnaleźć symbole złożone $\mathrm{z}$ tych trzech elementów: Nr Adm. 18/8; Nr Adm. 18/12 ${ }^{56}$. Zdarzało się i tak, że do znaku pisma dołączano numer oznaczający rok kalendarzowy. Wówczas wyglądał on następująco: $\mathrm{Nr}$ Adm. 24/89/49; $\mathrm{Nr}$ Adm. 24/27/50 57. Trzeba pamiętać, że znaki pism dotyczące Zarządu Miejskiego, Miejskiej Rady Narodowej i jej Prezydium były konstruowane w analogiczny sposób. W sposobie rejestracji kancelaria nie była do końca konsekwentna. Niekiedy pisma podlegały rejestracji w dzienniku podawczym, o fakcie tym świadczy postać znaku akt jednego z nich: L. Dz. 15/22/49, gdzie pierwsza liczba stanowiła symbol ewidencyjny pisma zarejestrowanego w głównym dzienniku kancelarii, natomiast liczba kolejna oznaczała pozycję dziennika wydziałowego, liczba 49 określała zaś rok kalendarzowy ${ }^{58}$. Zdarzały się też znaki pism bardziej rozbudowane, np. L. IX-5/63/49, gdzie pierwszy element jest prawdopodobnie numerem $\mathrm{z}$ wykazu akt, drugi to kolejna liczba ze spisu spraw, a następny może oznaczać numer z dziennika podawczego ${ }^{59}$. Wydaje się zatem, że w niektórych przypadkach, pomimo przejścia kancelarii na system bezdziennikowy, dziennik podawczy został zachowany jako niezbędna pomoc ewidencyjna. Wniosek taki oparto na fakcie występowania jeszcze w 1949 r. znaków pism, w których jeden z elementów stanowił liczbę dziennika podawczego.

Po merytorycznym załatwieniu sprawy referent sporządzał brulion odpowiedzi zawierający: część zasadniczą - treść urzędową, nad nią adres, a pod treścią podpis referenta. Należało również zamieścić termin odpowiedzi i informację o liczbie załączników. Na brulionie znajdował się ponadto podpis aprobanta (kierownika referatu).

Następny etap obiegu pisma to sporządzanie czystopisu. Nie jest do końca jasne, kto tę czynność wykonywał. Niewykluczone, że koncepty pism trafiały do

\footnotetext{
${ }^{56}$ AmP, sygn. 76, Pisma do nadleśnictwa z 27 VI 1949 r. Liczba pierwsza stanowi numer teczki z wykazu akt, według którego nr 18 nosi tytuł „Rolnictwo”, pisma więc były treściowo adekwatne co do rzeczowej systematyzacji ich łączenia.

57 Tamże, sygn. 90, s. 23 i 97. Odpowiednio są to pisma dotyczące spraw społecznych, skierowane do Wojewody Lubelskiego i do Wydziału Powiatowego.

${ }^{58}$ Prawdopodobnie takie rozwiązanie wynikało ze specyfiki akt sądowych. Zob. tamże, sygn. 125, s. 99, Pismo ZM do Prokuratora Sądu Okręgowego w Lublinie.

59 Tamże, sygn. 114, s. 32, Pismo ZM z 17 V 1949 r.
} 
hali maszyn, gdzie były przepisywane przez maszynistkę ${ }^{60}$, ewentualnie wracały do referentów, zobowiązanych do skolekcjonowania czystopisu. Przygotowane do wysłania pismo podpisywał burmistrz lub jego zastępca. Brulion odpowiedzi zwracano komórce organizacyjnej, w której załatwiano sprawę merytorycznie. Jeśli było to pismo kończące sprawę, akta dołączano do właściwej przedmiotowo teczki, względnie podteczki ${ }^{61}$, a jeśli nie - odkładano je do teczki przeznaczonej na sprawy terminowe. Od personelu kancelaryjno-biurowego wymagano bardzo dobrej znajomości wykazu akt, ponieważ było to podstawą sprawnego dotarcia do właściwego pisma ${ }^{62}$.

Sprawy periodyczne, takie jak sprawozdania okresowe, podlegały jednorazowej rejestracji. Instrukcja kancelaryjna uwzględniała także sprawy niepodlegające rejestracji, do nich należały druki, prasa, rachunki, pisma o charakterze zawiadomień. Otrzymywały one w ramach numeru: skrót nazwy referatu oraz kolejną pozycję wykazu akt (numeru teczki). Trzeba też zauważyć, że pisma tajne i poufne były rejestrowane i przechowywane przez sekretarza. Dokumentacja, jaka narastała w toku bieżącej działalności Zarządu, była przechowywana w registraturze. To referenci w ramach swoich obowiązków łączyli pisma w sprawy, przechowywali teczki. Było kilka rodzajów teczek. Trzy grupy teczek podręcznych: „sprawy do załatwienia”, „do podpisu” oraz „terminowe” dla spraw wyczekujących odpowiedzi w określonym terminie. Akta spraw załatwionych tymczasowo były przechowywane w tzw. „terminatkach”, składających się z trzech lub sześciu teczek oznaczonych konkretnymi datami lub poszczególnymi dekadami miesiąca, stosownie do terminu ostatecznego załatwienia. Przepisy kancelaryjne przewidywały również prowadzenie odrębnych teczek dla spraw dotyczących zebrań organów ustrojowych (z wyszczególnionym napisem „na zebrania Rady Komisji”) oraz dla spraw niezwykle pilnych.

Spośród rodzajów dokumentacji wchodzącej w skład akt spraw należy też wyróżnić sprawozdania, okólniki i zarządzenia. W kancelarii narastały ponadto pomoce ewidencyjne, posiadające formę ksiąg. Stanowiły je księgi protokołów posiedzeń Miejskiej Rady Narodowej, Zarządu Miejskiego, Komisji oraz księgi

\footnotetext{
${ }^{60}$ Protokoły Prezydium MRN sugerują istnienie jedynie dwóch pracowników wykonujących czynności stricte kancelaryjne, tj. maszynistki i kancelisty. Zob. tamże, sygn. 1, s. 134, Protokół MRN z zatwierdzeniem tabeli stanowisk w Referacie Organizacyjnym ZM (od 1 I 1949 r.).

${ }^{61}$ W myśl zarządzenia nr 4/49 wydanego przez burmistrza ZM w Puławach 22 IV $1949 \mathrm{r}$. podziału takiego dokonywali kierownicy poszczególnych referatów. Zob. tamże, sygn. 34, s. 29.

${ }^{62}$ Tamże, sygn. 28, Regulamin wewnętrzny ZM z 1947 r.
} 
inspekcyjne ${ }^{63}$. Każdy protokół otrzymywał w obrębie roku kolejny numer. Tego typu dokumentację przechowywano w segregatorach, a po upływie roku kalendarzowego oprawiano w księgi. Instrukcja kancelaryjna nie precyzowała, w jaki sposób należy układać akta w trakcie ich narastania. Trzeba zaznaczyć, że również przepisy przedwojenne nie wyjaśniały tej kwestii. Dopiero instrukcja kancelaryjna z 1948 r. dla ministerstw oraz inne instrukcje stosowane przez urzędy administracji państwowej zalecały takie układanie w obrębie sprawy oraz spraw w teczce, jakie wymuszała budowa segregatoró $w^{64}$. Sprawę zarejestrowaną pod numerem pierwszym $z$ reguły umieszczano na spodzie segregatora, natomiast pod numerem ostatnim w spisie spraw - na wierzchu ${ }^{65}$. W teczkach sprawom ostatecznie załatwionym przeważnie nadawano układ chronologiczny lub alfabetyczny, w zależności od specyfiki materiału aktowego ${ }^{66}$.

Instrukcja kancelaryjna Zarządu w Puławach zalecała łączenie akt mechanicznie (w segregatory bądź skoroszyty). Nasuwa się zatem wniosek co do sposobu układania pism w trakcie ich narastania. Przekazanie teczek do składnicy akt poprzedzone było nadaniem porządku chronologicznego, zgodnie z zasadą, że wcześniejsze pismo znajdowało się na wierzchu.

Niemniej istotny był opis teczki według wytycznych instrukcji kancelaryjnych, składający się z nazwy zakładu pracy, nazwy komórki organizacyjnej, hasła teczki z wykazu akt, znaku akt oraz daty założenia i zakończenia teczki ${ }^{67}$. Przepisy instrukcji puławskiego Zarządu nie określają dostatecznie jasno sposobu opisu teczki. Wspominają jedynie o konieczności nadania teczce odpowiedniej numeracji i tytułu. W zespole zachowały się trzy oryginalne teczki z 1949 r. Są to teczki wiązane, posiadające nadruki haseł z wykazu akt, ze szczegółowym opisem zawartości. Prawdopodobnie tego typu obwoluty były przygotowywane dla wszystkich zarządów gminnych, a puławski Zarząd po prostu je zamawiał. Urzędnicy

${ }^{63}$ Podobny rodzaj dokumentacji kancelaryjnej narastał w kancelarii gdańskiej Wojewódzkiej Rady Narodowej w latach 1945-1950 (oprócz wymienionych pomocy ewidencyjnych autorka wymienia również dzienniki podawcze korespondencji wpływającej i wychodzącej, o których nie wspomina instrukcja puławskiego Zarządu). Zob. A. Przywuska, Kancelaria Gdańskiej Wojewódzkiej Rady Narodowej w latach 1945-1950, „Archeion” T. 70, 1980, s. 124.

${ }^{64}$ Wraz z wprowadzeniem systemu kancelaryjnego bezdziennikowego zaprzestano szycia akt. Narastające akta spraw przechowywano luźno w teczkach lub łączono w segregatory. Postanowienia w tej kwestii są zresztą aktualne do dziś. Por. I. Radtke, dz. cyt., s. 16.

${ }^{65}$ S. Sierpowski, D. Matelski, Dzieje archiwistyki polskiej. Wybór źródeł, Poznań 1988, s. 114. Por. I. Radtke, Kancelaria współczesna, „Archeion” T. 100, 1999, s. 37.

${ }^{66}$ I. Radtke, dz. cyt., s. 16.

${ }^{67}$ Tamże, s. 17. 
dopisywali jedynie numer z wykazu akt, rok założenia teczki oraz odbijali stempel: "Zarząd Miejski w Puławach”. Gotowe teczki w pewnym sensie zwalniały urzędników z obowiązku sporządzania pełnego opisu, stąd niedociągnięcia, przejawiające się brakiem takich elementów, jak nazwa komórki organizacyjnej czy znaku akt.

Akta w teczkach były grupowane na podstawie wykazu akt oraz podobieństwa treściowego pism. Poszczególne numery teczek oraz symbole literowe rejestrów kancelaryjnych przyporządkowane zostały, wspomnianym już, czterem referatom Biura Zarządu ${ }^{68}$. Teczka oznaczona numerem 2, zatytułowana „Sprawy osobowe członków organów gminy i pracowników gminnych"69 , grupowała pisma dotyczące spraw wyborów członków Miejskiej, Powiatowej Rady Narodowej oraz Zarządu Miejskiego. Ponadto dla każdego pracownika Zarządu prowadzono osobne teczki osobowe. Kolejna teczka „Budżety: administracyjny, zakładów i przedsiębiorstw"70 $^{\text {"70 }}$ oznaczona numerem 8 , zawierała sprawy ogólne związane z wykonywaniem budżetu i jego sprawozdawczością. Teczka posiada także adnotacje. Pierwsza odnosi się do prowadzenia oddzielnych podteczek dla każdego przedsiębiorstwa, w których obowiązywały odrębne budżety, druga natomiast do korespondencji poszczególnych działów budżetu, która miała być odkładana w odpowiednie teczki rzeczowe. I wreszcie teczka ostatnia, nosząca tytuł „Opieka społeczna, koszty leczenia, sprawy inwalidzkie, bezrobocie, emigracyjne i ubezpieczeń społeczny$\mathrm{ch}^{171}$ o numerze 24 . W tego rodzaju teczkach narastała dokumentacja dotycząca takich spraw, jak podania o zapomogi, wnioski o przyznanie świadczeń opieki społecznej, korespondencja z zakładami ubezpieczeniowymi i in. W osobnych teczkach odkładano pisma dotyczące spraw przewidzianych rejestracją w rejestrach kancelaryjnych. Trudno natomiast stwierdzić, czy rzeczywiście zawartość odpowiadała wydrukowanemu opisowi teczki, ponieważ podczas porządkowania zespołu niemożliwe było zachowanie oryginalnego układu (akta były w rozsypce) ${ }^{72}$.

Referenci przechowywali teczki do momentu, kiedy były im potrzebne do bieżącej pracy. Po upływie tego czasu należało je przekazać, za zgodą burmistrza, do składnicy akt (wyjątek stanowiły okólniki, znajdujące się w bibliotece Zarządu Miejskiego). Informacje na temat prowadzenia składnicy akt są bardzo skromne. Wiadomo jedynie, że powinien znajdować się tam wykaz akt, na

\footnotetext{
${ }^{68}$ AmP, sygn. 34, s. 29, Zarządzenie burmistrza Zarządu Miejskiego w Puławach nr 4/49.

69 Tamże, sygn. 30.

70 Tamże, sygn. 59.

${ }^{71}$ Tamże, sygn. 93 (w inwentarzu zespołu jednostka ta oznaczona jest sygnaturą 92).

${ }^{72}$ M. Trojanowska, Wstęp do inwentarza zespołu Akta miasta Puław, Lublin 1971 (maszynopis w czytelni Archiwum Państwowego w Lublinie).
} 
podstawie którego układano teczki. Natomiast brakowanie akt i ich przekazywanie do Archiwum Państwowego regulowały odrębne przepisy, jednakże nie udało się do nich dotrzeć.

Począwszy od 1949 r., w konsekwencji wprowadzenia registratury zdecentralizowanej, wszystkie czynności związane z prowadzeniem teczek przejęli referenci poszczególnych komórek organizacyjnych Zarządu.

\section{Wnioski}

Działalność kancelarii puławskiego Zarządu Miejskiego nie odbiegała w sposób szczególny od innych kancelarii miejskich funkcjonujących w tym okresie. W zasadzie można przyjąć, że zaraz po wojnie kancelarie prowadzone były systemem dziennikowym, a następnie pod wpływem nacisków władz przechodziły na system bezdziennikowy, oczywiście proces unowocześniania kancelarii przebiegał z różnym skutkiem. Taki wniosek można wysnuć na podstawie analogii funkcjonowania innych kancelarii tego typu, przedstawionych w literaturze przedmiotu. Jednak zbyt mało jest zbadanych kancelarii miejskich tego okresu, aby jednoznacznie stwierdzić, jaki był stan faktyczny.

Nie ulega natomiast wątpliwości, że cechą wyróżniającą kancelarię Zarządu Puław jest rzeczowy wykaz akt, a - co ciekawe - w Polskim słowniku archiwalnym nie ma definicji tego wykazu. Odbiegał on nieco od typowych, strukturalno-rzeczowych, powszechnie wówczas stosowanych. Pozostaje pytanie, czy była to praktyka szerzej stosowana w kancelariach, przede wszystkim miejskich. Pewnie zdarzały się takie sytuacje, chociaż w prześledzonych przeze mnie kancelariach innych miast (przede wszystkim Ziem Zachodnich i Północnych) w powszechnym stosowaniu były raczej wykazy strukturalno-rzeczowe.

Wydaje się, że temat nie jest zamknięty, a przedstawiony problem może być przyczynkiem do dalszej analizy. Można pokusić się o próbę porównawczą kancelarii różnych zarządów miast np. Lubelszczyzny, chociaż pewną trudność w tym przypadku może stanowić brak zachowanego materiału źródłowego. 


\section{Summary}

\section{Organization of the Work of the Administrative Office of the Town Government in Puławy in 1944-1950}

The article presents the issues of the organization of the administrative office in the town government in Puławy in 1945-1950. The source materials are the archival materials from the records of the Town of Pulawy (held in the State Archive in Lublin). Their analysis allowed the author to recreate precisely the functioning of the administrative office while using it used the register system and from 1949 - the case-based filing system. The modernization of the administrative office was possible due to the introduction of office standards - office instructions and the subject index of records, which was different from the commonly used structural-subject records.

KEYworDs: Puławy, town administrative office, register system, case-based filing system, office standards. 